\title{
Reproduction and growth in a Neotropical arboreal mouse: Oecomys rutilus (Sigmodontinae: Cricetidae) in French Guiana
}

\author{
François Catzeflis ${ }^{1 *(\mathbb{C})}$ \\ ${ }^{1}$ Université de Montpellier, Institut des Sciences de l'Evolution, Montpellier, France \\ "Corresponding author: François Catzeflis, e-mail: francois.catzeflis@umontpellier.fr
}

\begin{abstract}
CATZEFLIS F. Reproduction and growth in a Neotropical arboreal mouse: Oecomys rutilus (Sigmodontinae: Cricetidae) in French Guiana. Biota Neotropica. 19(2): e20180697. http://dx.doi.org/10.1590/1676-0611BN-2018-0697
\end{abstract}

\begin{abstract}
Postnatal growth and development of the small Neotropical mouse Oecomys rutilus (Sigmodontinae: Cricetidae) were investigated from birth to day 143, in the laboratory. Morphometric measurements at age of 3 days, of both sexes combined, revealed body weight to be $3.4 \pm 0.3 \mathrm{~g}$, mean tail length as $27.4 \pm 1.1 \mathrm{~mm}$, and mean hind foot length as $9.3 \pm 0.7 \mathrm{~mm}$. Body weight was found to increase steadily until at least 69 days, whereas the instantaneous growth rates of other measurements declined earlier: the daily growth of hind foot length declined to a minimum at age of 24 days, and the growth of tail and of ear declined by the age of 33 days. Average litter size for 12 captive births was 2.5 , ranging from 2 to 3 . The preserved eye crystalline lens was weighted in 23 captive-born animals of known age, allowing a rough estimate of the age of reproduction in wild-caught animals. Based on the inferred relation between eye-lens weight and age, the youngest reproductive (pregnant) wild-caught females had an estimated age of 90 and 95 days.
\end{abstract}

Keywords: allometry, Gompertz model, rodents, eye-lens weight, life history.

\section{Reprodução e crescimento de um rato arbóreo neotropical: Oecomys rutilus (Sigmodontinae: Cricetidae) na Guiana Francesa}

\begin{abstract}
Resumo: O crescimento pós-natal e o desenvolvimento do pequeno roedor neotropical Oecomys rutilus (Sigmodontinae: Cricetidae) foram investigados desde o nascimento até o dia 143, em laboratório. Mensurações morfométricas na idade de 3 dias, de ambos os sexos combinados, revelaram a massa corporal de 3,4 $\pm 0,3 \mathrm{~g}$, comprimento médio da cauda de $27,4 \pm 1,1 \mathrm{~mm}$, e comprimento médio do pé de $9,3 \pm 0,7 \mathrm{~mm}$. A massa do corpo aumentou rapidamente até o dia 69 , enquanto as taxas de crescimento instantâneo de outras medidas diminuíram mais cedo: o crescimento diário do pé diminuiu para o mínimo na idade de 24 dias, e os crescimentos da cauda e da orelha diminuíram na idade de 33 dias. O tamanho de prole médio para 12 nascimentos em cativeiro foi de 2,5, variando de 2 a 3 . As lentes preservadas do cristalino do olho foram pesadas em 23 animais nascidos em cativeiro de idades conhecidas, permitindo fazer uma estimativa da idade de reprodução em animais capturados na natureza. Baseado na relação inferida entre peso da lente do cristalino e idade, as mais jovens fêmeas (prenhes) capturadas na natureza tiveram uma estimativa de 90 a 95 dias de idade.
\end{abstract}

Palavras-chave: alometria, modelo de Gompertz, roedores, peso do cristalino do olho, história de vida.

\section{Introduction}

Being able to ascertain age is important in studies of mammals, as the knowledge of age structures of populations is necessary for understanding the life history strategies (Martin et al., 2011). When samples of field-caught mammals are taken from a population, it is usually impossible to assign a known age to any specimen unless birth was observed and the individual was uniquely marked for later identification. The procedures for establishing absolute and relative ages can be standardized by study of individuals of known age (Morris 1972), and this is were captive-born animals can bring much useful data. Increases in linear dimensions and weight may be useful indicators of age during the earliest portions of a mammal's life but rapidly lose their usefulness once adult dimensions are reached (Hoffmeister and Zimmerman 1967; Morris, 1972).

The weight of the eye crystalline lens increases with age and thus many studies of age structures of populations have relied on weighing the lenses removed from mammal specimens (see Lord 1959 and review in Friend 1967; Morris 1972). Several investigators (Dapson and Irland 1972; Myers et al. 1977) found eye lens weight increasing linearly during approximately the first year of life in several species of myomorph rodents. For example, Birney et al. (1975) have shown that, in the cotton rat Sigmodon hispidus, both body weight and eye lens weight were regularly growing with age during the first weeks 
of life, inasmuch that a strong (i.e. within $95 \%$ confidence intervals) correlation between age and weight lasted much less for body (until to ca. 70 days) than for the eye lens (until to ca. 150 days). In this study, eye lens weights of 22 captive-born specimens with known age will provide the first data linking age and eye lens growth in a small arboreal Neotropical rodent.

Here we are interested in the reproduction and in ontogenetic allometry, ie the description of differential growth in individual ontogeny (Gould, 1966; D’Andrea et al., 1996) of a neotropical Cricetidae. By rearing small arboreal mice in captivity, we aim at addressing changes of one part to another during growth, through measurements taken in six metric features at different ages after birth.

In early life, growth in most kinds of mammals is continuous, but some structures cease growth sooner than others, hence not all morphological features are useful for aging individuals in a population. Growth rates of mammals are most commonly described by the sigmoidal function of the Gompertz model, although other models sometimes perform equally well (Zullinger et al., 1984).

It is a matter of common observation that not all parts of the body grow at a uniform rate (D'Andrea et al., 1996). A newborn mouse, for example, is obviously short-tailed, relative to body length, as contrasted with a mouse that has attained adult proportions (Green and Fekete, 1933).

The Neotropical Oecomys rutilus Anthony, 1921 (Sigmodontinae: Cricetidae) is a small-sized oryzomyine (average weight of $18-22$ g), externally characterized by soft fur, short and broad hindfeet with relatively long toes, and a tail moderately longer than the head and body (tail length about $115 \%$ of head and body length). The fur is soft, and moderately long in length. Dorsal coloration of adults varies from tawny to reddish brown, bright in tone; ventral pelage color is pure white. Tail hairs relatively long, typically concealing distal scale rows and forming conspicuous terminal tuft (5-11 mm per Voss et al. 2001). Females possess eight mammae (Carleton and Musser, 2015).

In French Guiana (Voss et al. 2001; Catzeflis et al., 2014), nearly all examples of O. rutilus were captured in primary forest, with few animals in secondary growth. At Trois-Sauts Amerindian villages, the arboreal $O$. rutilus has also been caught in traditional houses, together with the more common and slightly larger $O$. bicolor (Catzeflis, 2012). As so far documented, the geographic range of O. rutilus adheres to the Guiana subregion of Amazonia, along with those of $O$. auyantepui and O. rex (Carleton and Musser, 2015).

This study brings an additional taxon to the data base of growth patterns in New World cricetid rodents examined by Creighton and Strauss (1986), and it is the first case for an arboreal sigmodontine from the Neotropical rainforests.

\section{Materials and Methods}

Wild-caught Oecomys rutilus come from the primary rainforest (upland, terra firme) from Les Nouragues scientific station (municipality of Regina, French Guiana), and were obtained in July 1998 and in May 1999, with due permission from the acting director of the campsite.

Two males (N-330; N-251) and one female (N-217) were caught via canopy traps in large trees at heights 32,14 , and $15 \mathrm{~m}$, respectively; one female (N-351) was caught at $3 \mathrm{~m}$ height when visiting the food stores of a wooden lodge of the camp. The four wild-caught breeders passed a routine health examination at the French Veterinary Services (Department of Agriculture and Forests) at Cayenne in September 1998 and June 1999, respectively.

Animals were kept in a large terrarium (in cm: 400 length x 60 breadth $x 80$ height) filled by 5 to $7 \mathrm{~cm}$ of earth mixed with vegetablemould, and containing a few dry natural branches. Artificial wooden nest-boxes $(12 \times 12 \times 12 \mathrm{~cm})$ with a single circular opening (diameter $30 \mathrm{~mm}$ ) were randomly scattered on the ground, with always at least two more nest-boxes than pairs of adult animals.

Food (various seeds, grains and fruits) and water were given ad libitum.

We checked the content of the nest-boxes every 3 to 5 days. When discovering a new litter, we refrained from handling the mother and youngs until the third day of age. Then, at each control, we gently seized each juvenile for taking the following measurements in six metric features: weight (in grams), tail (without terminal hair-tuft; in $\mathrm{mm}$ ); hind foot (without claws), vibrissae from the muzzle (mystacial vibrissae), vibrissae from above eye (superciliary vibrissae), and ear (from inner notch).

Obviously many factors, such as litter size, age and condition of the mother, differential mortality of smaller young, and laboratory conditions, influence the growth rates of individual young (Myers and Master, 1983). Yet, the mean values approximate the general pattern of growth in these features for a typical individual (Creighton and Strauss, 1986). Data were also recorded on the mean length of the gestation period.

Upon termination of the breeding experiments (27 August 2000), animals were sacrificed and preserved as vouchers deposited in the collections of the Museum National d'Histoire Naturelle (MNHN, Paris). For 23 specimens (see vouchers numbers in Appendix 1) with known age, the eye-lens (eye crystalline) could be preserved, cleaned, dried, and weighed with a dedicated analytical balance (model AE-240 of Mettler-Toledo company, Bekasi -Indonesia) to the nearest tenth of mg. Among various "saturation" models available for linking eye-lens weight and age, we selected the Gompertz equation as implemented in the software PAST (Hammer et al., 2011). Other saturation models do exist, such as Bertalanffy, or Michaelis-Menten models, or else polynomial, but we used Gompertz' for the sake of comparison with published studies (see discussions in Creighton and Strauss, 1986; Zullinger et al., 1984).

The parameters obtained for each metric feature were the asymptotic length (mm) or mass (g) A; the constant growth rate (b) and the age at the first inflexion point of the growth curve (c) in the Gompertz equation. Estimates of adult size were based either on measurements of wild-caught specimens or on the asymptotic size calculated from the growth curves using the Gompertz model.

Choosing $90 \%$ of the asymptotic size provides a landmark from within the range of observed data that indicates the age at which a constant proportion of total exponential growth has occurred (further details in Creighton and Strauss, 1986). For assessing the role of sexual size dimorphism, parametric (paired t-tests) and non-parametric tests (MannWhitney) were done with the software PAST (Hammer et al., 2011).

For comparing the estimated asymptotic growth values of the captive-bred animals, we used biometric data for 40 wild-caught Oecomys rutilus (20 females, 20 males) originating from different localities in French Guiana (see Appendix 2 for details). Our data set 
includes 3 juveniles (with only two erupted molars), 4 sub-adults (with three molars but no dental wear), and 33 adults. Adult wild-caught females include 7 pregnant and 4 lactating individuals.

All procedures with animals (captures in the wild, rearing in captivity, handling, euthanasy) followed the ethical guidelines of the American Society of Mammalogists for the use of wild mammals in research (Sikes and Gannon 2011).

\section{Results}

From the captive breeding colony, we obtained a total of 12 litters (on average 2.5 young per litter, from 2 to 3 ) between 25 August 1998 and 13 June 2000. Five consecutive litters are separed by intervals of 26 to 31 days (average 28.8 days), which suggests a gestation time of about four weeks. Reproduction in captivity occurred in May (2 births of litters), June (2), July (2), August (2), September (1), and October (3).

In French Guianan wild-caught animals, seven females were found pregnant, with a mean of 2.3 embryos (range from 1 to 3); pregnant and/or lactating females were caught in June (3 individuals), July (1), September (1), October (4), and November (2).

As previously observed in other sigmodontine rodents (see Voss, 1991, for Zygodontomys; or Percequillo et al., 2008, for Cerradomys), there is no sexual size dimorphism in wild-caught adult animals of O. rutilus (17 females versus 16 males: t-tests and/or Mann-Whitney tests: data not shown), thus growth measurements did not consider each sex separately.

The growth pattern was examined in six external variables, for which a minimum of 3 young animals could be measured at each of 25 different ages ranging from 3 to 143 days after birth, and the mean values are detailed in Table 1. (For the body weight, data span a much longer period up to 567 days, with 42 additional ages, each with at least 3 measures).

Plotting the absolute values (in $\mathrm{g}$ for the body weight, otherwise in $\mathrm{mm}$ for other variables) for the 25 age classes (Figure 1) indicates that maximum size is essentially reached by the age of 55 days.

The Gompertz model provides the following asymptotic values: Tail $92.5 \mathrm{~mm}$ (correlation $\mathrm{r}=0.739)$; Hindfoot $18.3 \mathrm{~mm}(\mathrm{r}=0.635)$, Ear 11.7 $\mathrm{mm}(\mathrm{r}=0.734)$, Mystacial vibrissae $36.3 \mathrm{~mm}(\mathrm{r}=0.680)$, Supraciliary vibrissae $23.3 \mathrm{~mm}(\mathrm{r}=0.672)$, and Body weight $17.9 \mathrm{~g}(\mathrm{r}=0.862)$.

Relative growth values are plotted on Figure 2, which shows that the first variable to reach $90 \%$ of its final (asymptotic) size is the Ear (at age 22 days), followed by the Hindfoot (at 24 days), the Supraciliary vibrissae (25 days), the Mystacial vibrissae and the Tail (30 days each). Finally, the body weight continues to grow for a longer span, reaching $90 \%$ of asymptotic completion by the age of 50 days.

The weight of the eye lens in captive-born animals (Figure 3 ) has a very steep growth during the first two months - from $0.9 \mathrm{mg}$ at age of 11 days to $8.1 \mathrm{mg}$ at age of 67 days -, and then the slope of the curve diminishes but the growth continues during the next 12 months, at least. The oldest animals (aged 405 and 430 days) have an eye lens weighting 14.4 and $15.4 \mathrm{mg}$, respectively. The examination of the growth of the eye-lens in 23 captive Oecomys rutilus of known ages $(\mathrm{N}=17$ ages ranging from 11 to 430 days) indicates a regular increase for that organ, and there is a rather good fit of the data to the Gompertz model (Akaike IC $=27.0 ; r=0.903$ ). Wild-caught animals (sample size of 40 individuals) have eye lens weights ranging from $3.0 \mathrm{mg}$ (a juvenile with only two erupted molars) to $14.1 \mathrm{mg}$ (an adult male with worn molars). After excluding 7 pregnant females from the data set of wild-caught animals, there is a good linear correlation $(\mathrm{r}=0.839, \mathrm{p}<0.0001, \mathrm{~N}=$ 52 ) between eye-lens weight and body-weight in the complete data set (30 wild-caught and 22 captive-born: see Figure 4).

\section{Discussion}

In Oecomys rutilus, the average litter size measured in captivity (mean of 2.5 youngs for 12 litters) is not different from the average number of embryos in wild-caught females (mean of 2.3 for 7 pregnant individuals; see also Catzeflis et al., 2018). And the values of this study are comparable to those found in an other small species of the genus - O bicolor -, with mean values ranging from 2.1 to 2.6 (Patton et al., 2000; Hice and Velazco, 2012; Catzeflis et al., 2018).

Interbirth intervals range from 26 to 31 days (average 29 days), but we caution that we have only five data; in a breeding colony of Zygodontomys brevicauda, interbirth intervals ranged from 24 to 28 days, with a mode at 25 days for 53 out of 71 observations (Voss et al., 1992).

In $O$. rutilus, the growth of newborn animals is very intense during the 30 first days, and then stabilizes around 52 to 55 days of age; a similar pattern is illustrated for a few taxa of Sigmodontinae by Creighton and Strauss (1986), as well as in various species of the Old-World murine genus Apodemus (Pelz et al., 1996). Among the five metric variables of this study, the length of the hind foot grows the fastest, as $90 \%$ of its asymptotic value is reached by the age of 24 days, with an average length of $16.6 \mathrm{~mm}$ to be compared with a mean of $18.5 \mathrm{~mm}$ in 33 adult wild-caught animals. The slower growing measures, as illustrated on Figure 2, are the Tail and the Ear length which reach $90 \%$ of their asymptotic value by the age of 33 days.

Asymptotic values (A) derived from Gompertz model are in adequacy with mean values for 33 adult wild-caught animals (W), although three variables are clearly smaller in captive bred animals: Tail length $(A=92.5 ; \mathrm{W}=98.6 \pm 5.5)$, Ear $(A=11.7 ; \mathrm{W}=14.2 \pm 0.8)$, and Weight $(\mathrm{A}=18.0, \mathrm{~W}=21.1 \pm 3.3)$. The other three measurements are similar between captive-bred and wild-caught animals: Hindfoot $(\mathrm{A}=$ $18.3 ; \mathrm{W}=18.5 \pm 0.8)$; Mystacial vibrissae $(\mathrm{A}=36.6 ; \mathrm{W}=37.3 \pm 2.9)$; and Supraciliary vibrissae $(\mathrm{A}=24.3 ; \mathrm{W}=25.2 \pm 3.1)$.

During the younger ages of $O$. rutilus, no potential effect of sexual differences could be evidenced, as shown by paired t-tests $(p=0.160$ for mean; $\mathrm{p}=0.199$ for median) or Mann-Whitney unpaired tests $(\mathrm{p}=$ $0.809 ; \mathrm{U}=10^{\prime} 480$ ) for comparing 26 males and 26 females aged 3 to 55 days after birth. This is similar to some other sigmodontine rodents, like Akodon lindberghi (De Conto and Cerqueira, 2007), for which no significant sexual size dimorphism is found during growth of the young in captivity.

We interprete the gestation length as ranging from 26 to 31 days (average of 29 days for 5 values), but this is only true if fecundation was occurring just after parturition. A value of 29 days for gestation in this arboreal oryzomyine compares well with other sigmodontine data presented by Moscarella and Aguilera (1999) such as 30 days for Sigmodon hispidus or Nectomys rattus, and 29 days for Holochilus brasiliensis and $H$. sciureus. 
Catzeflis, F.

Table 1. Average values (in mm. except for weight in $\mathrm{g}$ ) for six metric features in captive Oecomys rutilus aged from 3 to 143 days after birth.

\begin{tabular}{|c|c|c|c|c|c|c|c|}
\hline Age (days) & Tail & Hind foot & Ear & $\begin{array}{l}\text { Mystacial } \\
\text { vibrissae }\end{array}$ & $\begin{array}{l}\text { Superciliary } \\
\text { vibrissae }\end{array}$ & Weight & Sample size \\
\hline 3 & 27.4 & 9.3 & 3.8 & 6.7 & 4.3 & 3.4 & 5 \\
\hline 5 & 34.6 & 11.0 & 5.8 & 9.5 & 6.0 & 3.7 & 4 \\
\hline 6 & 36.5 & 11.3 & 6.0 & 9.8 & 6.5 & 4.8 & 3 \\
\hline 7 & 38.8 & 12.6 & 6.1 & 12.0 & 7.8 & 4.5 & 4 \\
\hline 18 & 68.2 & 16.3 & 9.6 & 24.8 & 16.8 & 8.5 & 5 \\
\hline 24 & 79.7 & 16.6 & 11.0 & 30.3 & 21.5 & 9.2 & 5 \\
\hline 31 & 83.9 & 17.4 & 10.8 & 33.8 & 22.8 & 12.6 & 4 \\
\hline 33 & 86.7 & 18.2 & 11.7 & 36.0 & 23.7 & 13.7 & 3 \\
\hline 52 & 93.3 & 18.3 & 11.6 & 36.0 & 23.3 & 16.5 & 7 \\
\hline 55 & 93.3 & 17.8 & 11.8 & 35.4 & 22.8 & 15.4 & 3 \\
\hline 59 & 91.5 & 17.3 & 11.8 & 34.8 & 22.3 & 15.9 & 6 \\
\hline 65 & 93.3 & 17.9 & 11.7 & 34.0 & 24.0 & 16.2 & 7 \\
\hline 66 & 94.0 & 17.8 & 11.7 & 34.0 & 23.7 & 16.1 & 3 \\
\hline 69 & 93.0 & 17.8 & 12.3 & 33.0 & 24.3 & 18.4 & 3 \\
\hline 72 & 90.8 & 17.5 & 11.6 & 34.5 & 23.3 & 16.5 & 5 \\
\hline 75 & 94.0 & 17.8 & 11.7 & 32.0 & 24.0 & 17.5 & 3 \\
\hline 85 & 91.7 & 17.7 & 11.7 & 34.0 & 22.7 & 16.5 & 3 \\
\hline
\end{tabular}

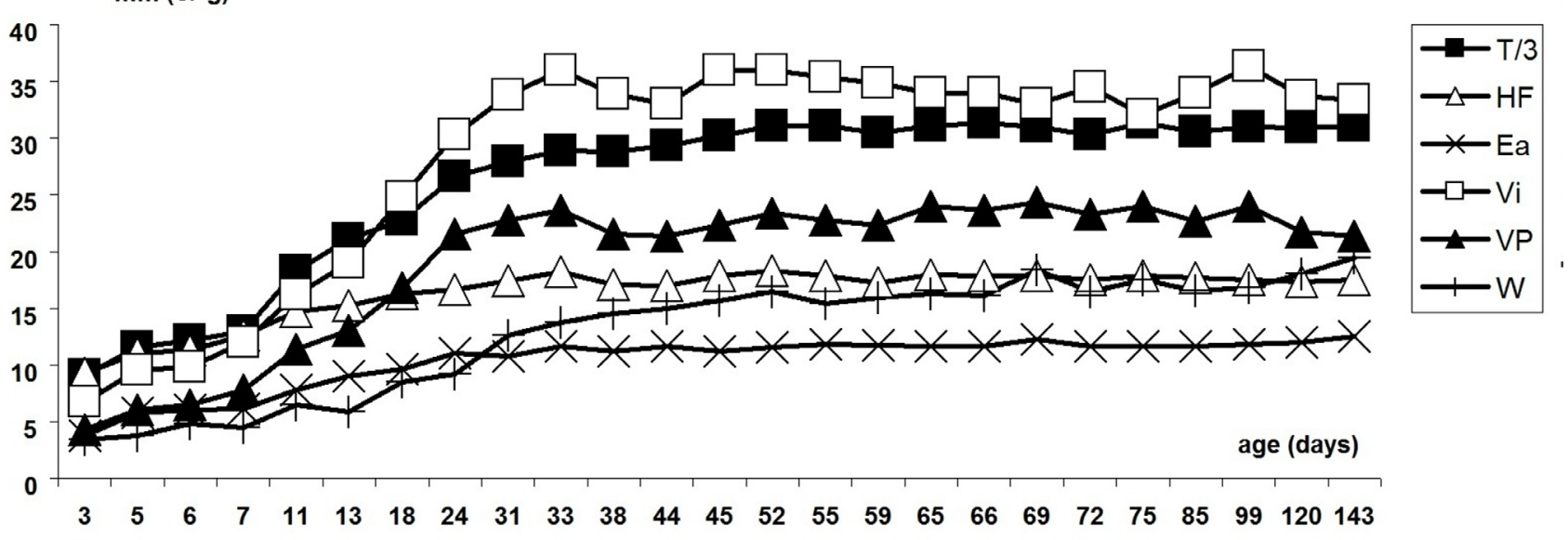

Figure 1. Growth values in captive bred Oecomys rutilus. Ages cover 25 classes ranging from 3 days after birth until 143 days, and each age class has at least 3 individuals measured. For the sake of clarity along the vertical axis, the Tail values have been divided by 3 .

Abbreviations: $\mathrm{T}=$ tail $\mathrm{HF}=$ hind foot; $\mathrm{Ea}=$ ear; $\mathrm{Vi}=$ mystacial vibrissae; $\mathrm{VP}=$ superciliary vibrissae; $\mathrm{W}=$ weight. $\mathrm{A}$ mere visual inspection suggests that maximum size is reached by the age of ca. 55 days. 


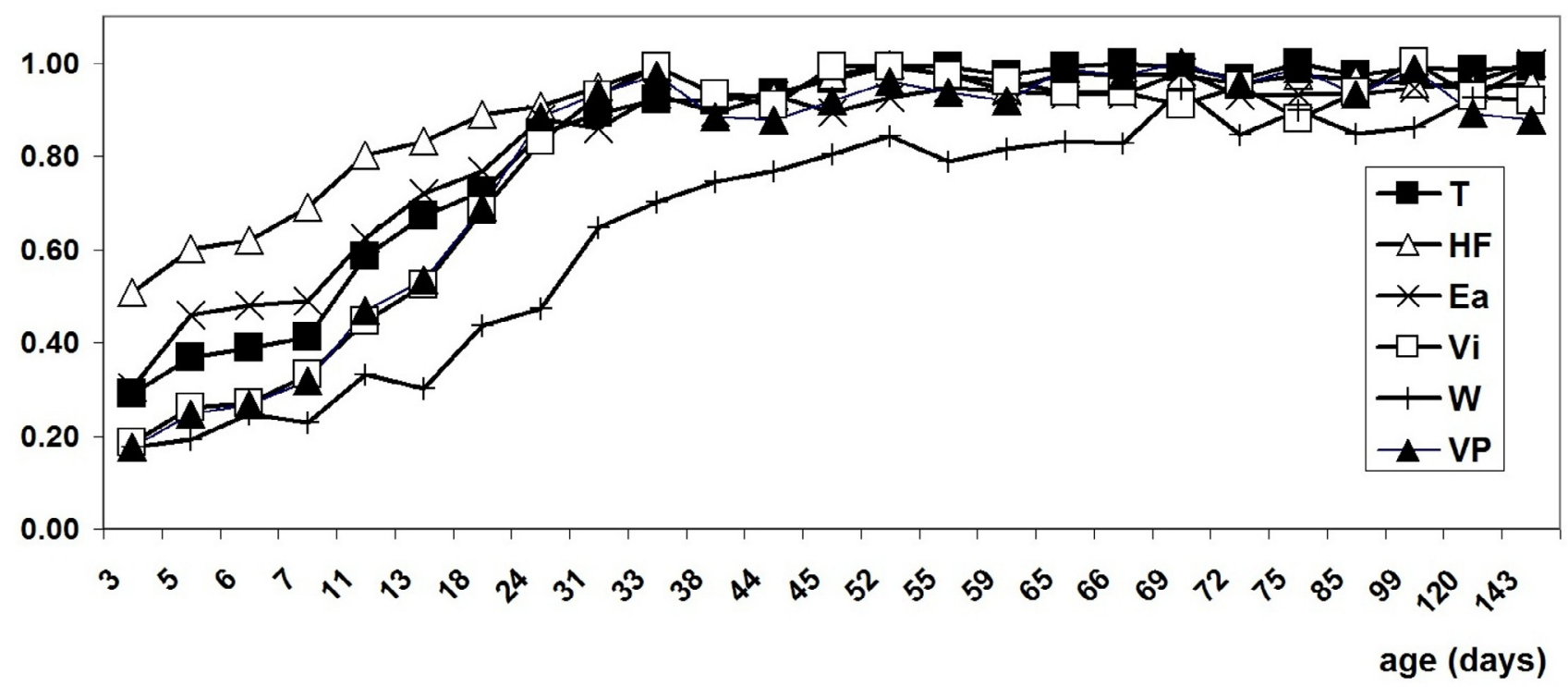

Figure 2. Relative growth values in captive bred Oecomys rutilus. Values expressed as percentage of maximum size reached after 55 days of age. Abbreviations as in Figure 1.

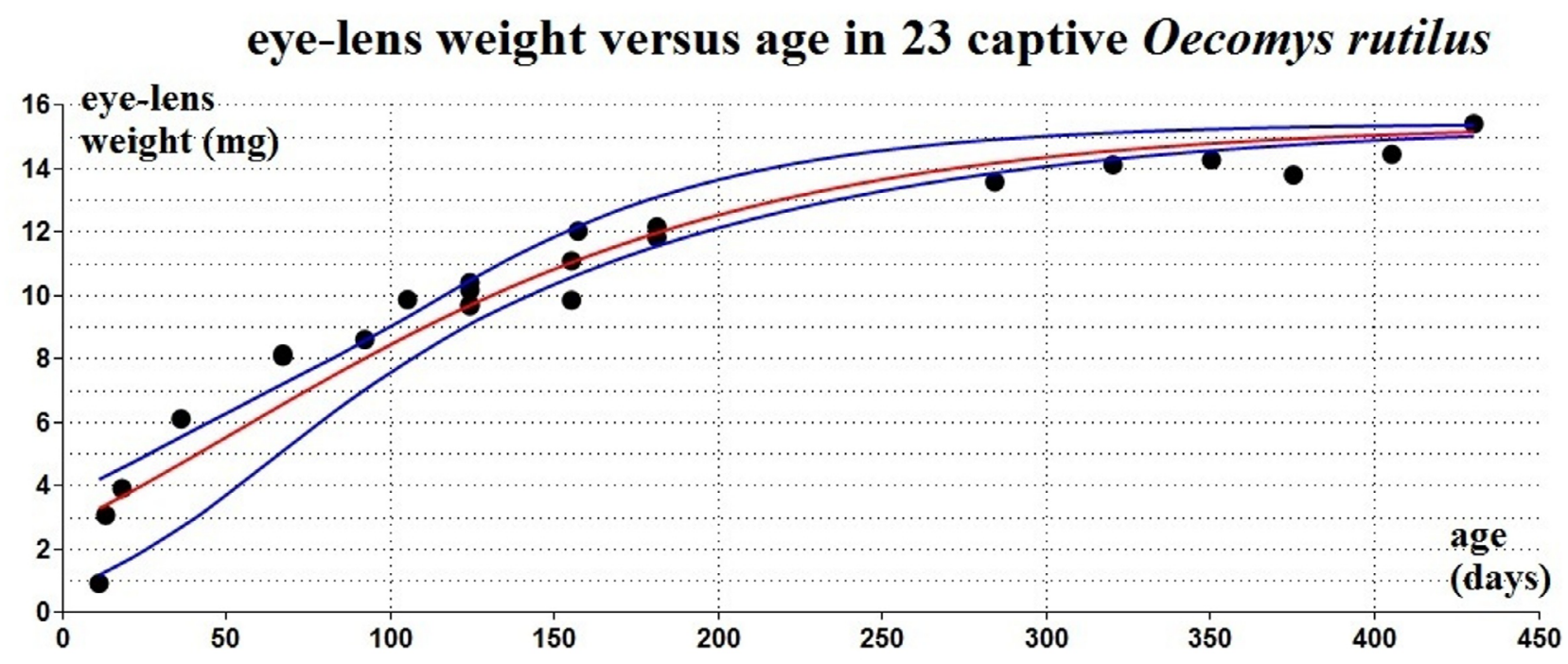

Figure 3. Eye lens weight in 23 captive bred Oecomys rutilus of known age. The curve (red) is a fit through the Gompertz model, bordered by $95 \%$ confidence intervals (blue).

Among the various "saturation" models available for linking eyelens weight and age, the Michaelis-Menten formula had the lowest Akaike IC (10.67) as compared to other models (see under Methods): its parameters $(y=a x /(b+x))$ were $a=17.4(95 \%$ confidence interval 16.3 to 18.5$)$ and $b=81.5$ (60.5 to 97.4$)$. Since the Gompertz model seems to be the one that best fits most mammalian growth curves (D'Andrea et al., 1996; Pillay, 2001; Zullinger et al., 1984), and for the sake of comparison with published studies, we applied this model to our data which resulted in a slightly higher Akaike IC (24.58) and in the following values for the main parameter: $\mathrm{a}=15.42$ ( $95 \%$ confidence interval 15.40 to 15.44$) ; \mathrm{b}$ $=-1.82(-2.17$ to -0.62$)$, and $\mathrm{c}=-0.01(-0.011$ to -0.006$)$.
Thus, it appears that the two wild-caught pregnant females with the smallest eye-lens ( 7.7 and $8.2 \mathrm{mg}$ ) have an age of about 90 and 95 days, respectively; our data would suggest that breeding can occur at an age as early as three months in females of Oecomys rutilus.

In studies of relative age, the technique of regression analysis is often used (Sokal and Rohlf 1995). With known-age individuals, age is a non-random variable and thus the quantity measured - such as eye lens weight - must be regressed on age. With samples of unknown age, age can be estimated by the method of inverse prediction (Dapson and Irland 1972; Sokal and Rohlf 1995) using values obtained from the measured variable (e.g., eye-lens or body weight), and Rowe et al. 


\section{body-weight (g) Eyes-lens versus body weight in Oecomys rutilus}

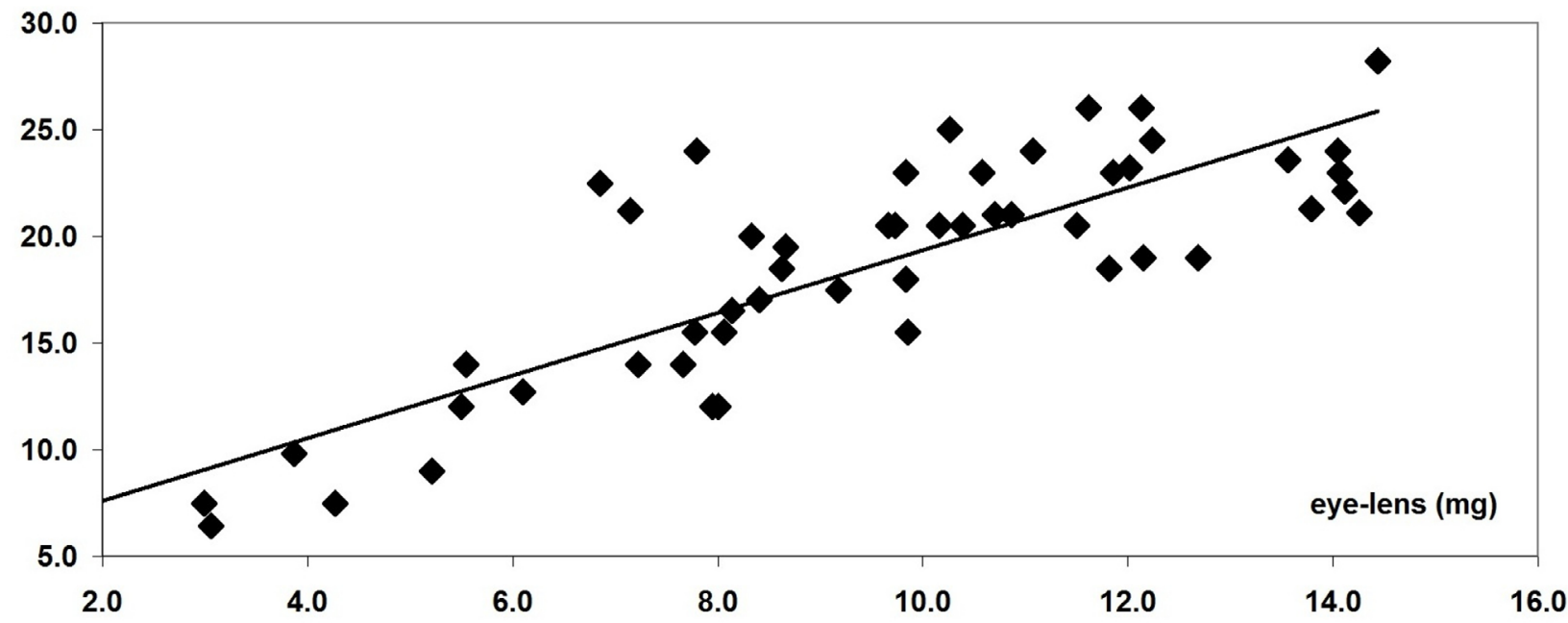

Figure 4. Eye-lens weight versus body weight in 52 Oecomys rutilus (30 captive-born and 22 wild-caught), with a good linear correlation ( $\mathrm{r}=0.839$; $\mathrm{p}<0.0001$ ) between these two variables.

(1985) have shown that, in house mice (Mus musculus), eye-lens weightage relationship were comparable in captive and wild-caught animals.

Thus, this study provides a first clue to assess the age in wild-caught specimens of the arboreal Oecomys rutilus, in the case preserved specimen have their eye-lens kept, cleaned, and dried for a precise weight. When animals can not be sacrificed in the field, a careful measure of their body weight can provide an indirect estimate of their age, via the rather good correlation between body weight and eye-lens weight.

\section{Supplementary material}

The following online material is available for this article:

Appendix 1

Appendix 2

\section{Acknowledgements}

The friendly hospitality of Pierre Charles-Dominique, director of the Nouragues field station, has been much appreciated, as was the technical help of Jean-François Mauffrey in the field. At Montpellier University, Delphine Bosch generously offered the use of a dedicated analytical balance for weighing eye-lenses at the Earth Sciences Department, and Elisabeth Cabirou executed the cleaning of the eye crystalline lenses with much care. With his usual kindness, Nilton Caceres translated the summary into Brazilian Portuguese, and Philip Dunn helped improve my awful English language - many thanks! This work has benefited from an "Investissements d'Avenir" grant managed by Agence Nationale de la Recherche (CEBA, ref. ANR-10-LABX-25-01).

\section{Authors' Contributions}

François Catzeflis is accountable for the whole of that article: Data acquisition, analysis, interpretation, and overall writing.

\section{Conflicts of interest}

The author declare that they have no conflict of interest related to the publication of this manuscript.

\section{References}

BIRNEY, E. C., R. JENNESS, and D. D. BAIRD. 1975. Eye lens proteins as criteria of age in cotton rats. J. Wildlife Manag. 39:718-728.

CARLETON, M. D., and G. G. MUSSER. 2015. Genus Oecomys Thomas 1906, p. 393 - 416. In: Mammals of South America, Volume 2. Rodents. J. L. Patton, U. F. J. Pardinas, and G. D’Elia (eds.). The University of Chicago Press, Chicago.

CATZEFLIS, F. 2012. A survey of small non-volant mammals inhabiting Wayampi Amerindian houses in French Guiana. Mammalia. 76:327-330.

CATZEFLIS, F., S. BARRIOZ, J.-F. SZPIGEL, and B. DE THOISY. 2014 Marsupiaux et Rongeurs de Guyane. Institut Pasteur de la Guyane, Cayenne, Guyane française.

CATZEFLIS, F. M., B. K. LIM, and C. R. DA SILVA. 2018. Litter size and seasonality in reproduction for Guianan rodents and opossums, Studies on Neotropical Fauna and Environment. https://doi.org/10.1080/016505 21.2018 .1528655

CREIGHTON, G. K., and R. E. STRAUSS. 1986. Comparative patterns of growth and development in cricetine rodents and the evolution of ontogeny. Evolution. 40:94-106.

D'ANDREA, P. S., A. C. HORTA, R. CERQUEIRA, and L. REY. 1996. Breeding of the water rat (Nectomys squamipes) in the laboratory. Lab. Anim. 30:369-376.

DAPSON, R. W., and J. M. IRLAND. 1972. An accurate method of determining age in small mammals. J. Mammal. 53:100-106.

DE CONTO, V., and R. CERQUEIRA. 2007. Reproduction, development and growth of Akodon lindberghi (Hershkovitz, 1990) (Rodentia, Muridae, Sigmodontinae) raised in captivity. Braz. J. Biol., 67:707-713.

FRIEND, M. 1967. A review of research concerning eye lens weight as a criterion of age in animals. New York Fish and Game Journal. 14:152-165.

GOULD, S. J. 1966. Allometry and size in ontogeny and phylogeny. Biol. Rev. 41:587-640. 
GREEN, C. V., and E. FEKETE. 1933. Differential growth in the mouse. Journal of Experimental Zoology. 66:351-370.

HAMMER, Ø., D. A. T. HARPER, and P. D. RYAN. 2011. PAST: Paleontological Statistics Software Package for Education and Data Analysis. Palaeontologia Electronica. 4:1-9.

HICE, C. L., and P. M. VELAZCO. 2012. The non-volant mammals of the Reserva Nacional Allpahuayo-Mishana, Loreto, Peru. Special Publications of the Museum of Texas Tech University. 60:1-135.

HOFFMEISTER, D. F., and E. G. ZIMMERMAN. 1967. Growth of the skull in the Cottontail (Sylvilagus floridanus) and its application to agedetermination. The American Midland Naturalist. 78:198-206.

LORD, R. D. 1959. The lens as an indicator of age in cottontail rabbits. The Journal of Wildlife Management. 23:358-360.

MARTIN, R. E., R. H. PINE, and A. F. DEBLASE. 2011. A Manual of Mammalogy: with Keys to Families of the World. Waveland Press, Long Grove, Illinois, USA.

MORRIS, P. 1972. A review of mammalian age determination methods. Mammal Review. 2:69-104.

MOSCARELLA, R. A., and M. M. AGUILERA. 1999. Growth and reproduction of Oryzomys albigularis (Rodentia: Sigmodontinae) under laboratory conditions. Mammalia. 63:349-362.

MYERS, K., J. CARSTAIRS, and N. GILBERT. 1977. Determination of age of indigenous rats in Australia. The Journal of Wildlife Management 41:322-326.

PATTON, J. L., M. N. F. DA SILVA, and J. R. MALCOLM. 2000. Mammals of the Rio Jurua and the evolutionary and ecological diversification of Amazonia. Bull. Am. Mus. Nat. Hist. 244:1-306.
PELZ, H.-J., H. GEMMEKE, R. HUTTERER, and U. JÜDES. 1996. Jugendentwicklung der Brandmaus Apodemus agrarius (Mammalia: Muridae) im Vergleich zu anderen Arten der Gattung. Bonner zoologische Beiträge. 46:233-247.

PERCEQUILLO, A. R., E. HINGST-ZAHER, and C. R. BONVICINO. 2008. Systematic review of genus Cerradomys Weksler, Percequillo and Voss, 2006 (Rodentia, Cricetidae, Sigmodontinae, Oryzomyini), with description of two new species from eastern Brazil. American Museum Novitates 3622:1-46.

PILLAY, N. 2001. Reproduction and postnatal developmental in the bush Karoo rat Otomys unisulcatus (Muridae, Otomyinae). J. Zool., Lond. 254:515-520.

ROWE, F. P., A. BRADFIELD, R. J. QUY, and T. SWINNEY. 1985. Relationship between eye lens weight and age in the wild House Mouse (Mus musculus). Journal of Applied Ecology. 22:55-61.

SIKES, R. S., and W. L. GANNON. 2011. Guidelines of the American Society of Mammalogists for the use of wild mammals in research. Journal of Mammalogy. 92:235-253.

SOKAL, R. R., and F. J. ROHLF. 1995. Biometry: the principles and practice of statistics in biological research. W. H. Freeman \& Co, New York.

VOSS, R. S. 1991. An introduction to the Neotropical muroid rodent genus Zygodontomys. Bull. Amer. Mus. Nat. Hist. 210:1-113.

VOSS, R. S., P. D. HEIDEMAN, V. L. MAYER, and T. M. DONNELLY. 1992. Husbandry, reproduction and postnatal development of the Neotropical muroid rodent Zygodontomys brevicauda. Laboratory animals. 26:38-46.

VOSS, R. S., D. P. LUNDE, and N. B. SIMMONS. 2001. The mammals of Paracou, French Guiana: A Neotropical lowland rainforest fauna. Part 2: Nonvolant species. Bull. Amer. Mus. Nat. Hist. 263:1-236.

ZULLINGER, E. M., R. E. RICKLEFS, K. H. REDFORD, and G. M. MACE. 1984. Fitting sigmoidal equations to mammalian growth curves. J. Mamm. 65:607-636. 